\title{
Variasi Genetik Plutella xylostella L. (Lepidoptera: Plutellidae) berdasarkan Gen Cytochrome C Oxidase I
}

\author{
Claudius F. Kairupana* ${ }^{*}$, Jantje Pelealua, Juliet M. E. Mamahita
}

aJurusan Entomologi, Pascasarjana, Unsrat, Manado

KATA KUNC I

Variasi Genetik

Gen COI

Plutella xylostella

\begin{abstract}
A B S TR A K
Daerah Modoinding dan Tomohon di Sulawesi Utara, dikenal sebagai daerah penghasil sayuran kubis di Indonesia. Sayuran kubis memiliki hama utama yaitu Plutella xylostella. Penyebab serangga ini dapat bertahan hingga saat ini karena adanya sifat resistensi akibat pemberian insektisida yang berlebihan. Penelitian ini dilakukan untuk menganalisis variasi pada gen cytochrome $\mathrm{C}$ oxidase I Plutella xylostella yang diperoleh dari dua lokasi yang berbeda, yaitu Modoinding dan Tomohon. Analisis sekuens menunjukkan adanya perbedaan pasang basa nukleotida dari sampel yang berbeda lokasi. Selain itu, variasi juga ditunjukkan pada sampel yang diperoleh dari basis data GenBank dengan adanya perbedaan 1-14 pasang basa nukleotida dengan spesimen pada penelitian ini. Hubungan kekerabatan gen COI P. xylostella keseluruhan sampel tergolong dalam variasi intraspesies dengan nilai jarak genetik berkisar antara 0-0,022 (0-2,20\%).
\end{abstract}

A B S T R A C T

Modoinding and Tomohon areas in North Sulawesi, are known as regions in Indonesia that produce a cabbage. The main pest of cabbage, Plutella xylostella. This insect can survive due to its resistance resulted from prolonged insecticide application. This study aims to analyze genetic variation of $\mathrm{COI}$ genes in P. xylostella from Modoinding and Tomohon areas. Sequence analysis showed there were differences in nucleotide base pairs between these locations. In addition, variations were also shown in samples obtained from the GenBank database with differences in 1-14 nucleotide base pairs with specimens in this study. The genetic relationship of $P$. xylostella $\mathrm{COI}$ gene in all samples was classified as intraspecific variation with genetic distance values ranging from 0-0,022 (0-2,20\%).

\section{TERSEDIA ONLINE \\ 01 Februari 2019}

\section{Pendahuluan}

Indonesia merupakan negara kepulauan dengan biodiversitas yang tinggi, artinya semua spesies baik hewan maupun tumbuhan sangat beragam dan bervariasi. Indonesia masuk dalam negara megabiodiversitas dengan urutan kedua setelah negara Brazil dibuktikan dengan melimpahnya sumber daya alam yang ada di Indonesia. Sumber daya alam yang melimpah dimanfaatkan dalam sektor pertanian, khususnya Sulawesi Utara yang merupakan provinsi dengan tingkat pendapatan ekonomi dari sektor pertanian yang cukup tinggi. Salah satu daerah yang mempunyai potensi di bidang pertanian adalah Kabupaten Minahasa Selatan dan Kota Tomohon (Kambey et al, 2016; Tarandung, 2016). Wilayah Modoinding (Minahasa Selatan) dan Tomohon (Kota Tomohon) dikenal sebagai penghasil sayuran berkualitas terutama sayuran kubis. Petani tanaman kubis memiliki masalah dengan larva kubis (Plutella xylostella L.) yang merupakan hama penting pada tanaman kubis (Pandeirot et al, 2015). Salah satu cara penanggulangan $P$. xylostella yang umum dilakukan oleh petani tanaman kubis di Sulawesi Utara khususnya wilayah Modoinding (Minahasa Selatan) dan Tomohon (Kota Tomohon) yaitu dengan melakukan penyemprotan insektisida. 
Hama $P$. xylostella dilaporkan resisten terhadap hampir semua insektisida sintetik yang umum digunakan oleh petani kubis seperti profenos, deltametrin, fipronil, abamektin, senyawa fosfat organik, piretroid sintetik, emamektin benzoat dan insektisida berbahan dasar bakteri Bacillus thuringiensis (Perez and Shelton, 1997; Udiarto dan Setiawati, 2007; Prabaningrum et al, 2013; dan Tarwotjo et al, 2014). Resistensi terhadap insektisida yang ditunjukkan oleh $P$. xylostella, merupakan salah satu contoh adaptasi serangga ini dengan kondisi lingkungannya dan berkaitan dengan kemampuan untuk bertahan pada kondisi lingkungan yang ditempatinya (Mallet, 1989).

Suatu populasi dapat beradaptasi terhadap perubahan yang terjadi di lingkungan sekitar, disebabkan oleh adanya variasi keanekaragaman genetik (Dharmayanti, 2011). Kondisi geografis dan tekanan lingkungan yang berbeda serta lokasi yang berjauhan dapat menyebabkan variasi genetik yang cukup tinggi pada suatu spesies (Wilson et al, 2013; Tallei et al, 2017). Salah satu alternatif terbaru untuk mempelajari keanekaragaman genetik adalah dengan menggunakan gen $\mathrm{COI}$ (Cytochrome $c$ oxidase I) yang bertindak sebagai kode batang DNA (DNA Barcode) pada hewan (Folmer et al, 1994).

Penelitian tentang hubungan genetik spesies $P$. xylostella yang berbeda lokasi, sangat penting untuk dilakukan, karena peran utama serangga ini yang merupakan hama utama pada tanaman kubis, memiliki pengaruh yang besar dalam adaptasinya terhadap perubahan lingkungan. Perubahan lingkungan menjadi ancaman keberlangsungan hidup ataupun kemampuan bertahan hidup serangga ini, sehingga memunculkan sifat resistensi yang dapat menjadi salah satu penyebab spesies serangga ini, menyesuaikan diri dengan kondisi lingkungan yang ekstrim (Jianhong et al, 2006).

\section{Material dan Metode \\ Isolasi DNA Plutella xylostella}

Imago yang diisolasi DNA nya berjumlah 3 sampel, masing-masing berasal dari Kecamatan Modoinding dan Kecamatan Tomohon Tengah. Isolasi DNA menggunakan metode spin-column based dengan set bahan dari kit Multisource Genomic DNA Miniprep Axygen (Lubenow dan Herold, 2008; Kolondam et al, 2013). Sayap dipisahkan dari toraks untuk memperkecil kontaminasi. Modifikasi dilakukan untuk memaksimalkan ekstraksi DNA $P$. xylostella dengan meningkatkan waktu lisis sel dari 10 menit menjadi 2 jam pada suhu $60^{\circ} \mathrm{C}$.

\section{Amplifikasi Gen COI dengan Teknik PCR}

Gen COI diperbanyak dengan metode PCR (polymerase chain reaction). Primer gen COI yang digunakan adalah Lep_F1 (5'-ATT CAA CCA ATC ATA AAG ATAT- 3') dan Lep_R1 (5'-TAA ACT TCT GGA TGT CCA AAAA- 3') (Hebert et al, 2004; Ashfaq et al, 2013). Dengan menggunakan set bahan $5 x$ firepool PCR Master Mix Ready-to-load (Solis BioDyne), komponen yang dicampur untuk amplifikasi gen COI yaitu $20 \mu \mathrm{l}$ Go Taq, 1,5 $\mu \mathrm{l}$ primer forward, 1,5 $\mu \mathrm{l}$

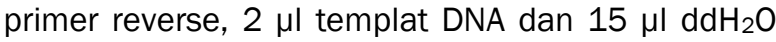
(air terdeionisasi). Pengaturan suhu pada mesin PCR untuk amplifikasi gen COI mengikuti kondisi reaksi yang dilakukan oleh Davenport (2014), yaitu denaturasi awal pada suhu $94^{\circ} \mathrm{C}$ selama 1 menit. Amplifikasi dilakukan sebanyak 35 siklus dengan suhu $95^{\circ} \mathrm{C}$ selama 30 detik untuk denaturasi, $50^{\circ} \mathrm{C}$ selama 30 detik untuk penempelan primer pada DNA templat dan $72^{\circ} \mathrm{C}$ selama 45 detik untuk pemanjangan DNA. Proses amplifikasi dilakukan menggunakan alat PCR Personal (Biometra). Proses sekuensing dilakukan oleh penyedia jasa sekuensing $1^{\text {st }}$ BASE Malaysia.

\section{Analisis Data}

Hasil sekuensing yang diperoleh dari perusahaan penyedia jasa sekuensing $1^{\text {st }}$ BASE Malaysia berupa kromatogram data urutan sekuens gen COI $P$. xylostella pada lokasi yang berbeda, disunting dengan menggunakan progam software komputer Geneious v5.6.4 (Kearse et al, 2012; Kolondam et al, 2013). Untuk mendapatkan keakuratan yang sesuai dalam pengolahan data, dilakukan penghapusan urutan data DNA bagian awal kurang lebih 30 nukleotida, untuk memisahkan sekuens DNA murni dari sisa sekuens primer. Utas hasil sekuensing yang menggunakan primer forward dan reverse dirakit dan diedit. Utas reverse dilakukan proses reverse and complement, kemudian dipadukan dengan utas forward menggunakan metode MUSCLE (Multiple Sequence Comparison by Log-Expectation) yang terintegrasi dalam program Geneious v5.6.4. Sekuens diubah dalam bentuk FASTA (fast alignment) untuk dianalisis. Penjajaran sekuens DNA menggunakan algoritma komputasi multiple sequence alignment (MSA) dalam program Multalin yang terintegrasi pada situs http://multalin.toulouse. inra.fr/multalin/ (Corpet, 1988). Penentuan reading frame menggunakan frame 2 untuk invertebrata jenis serangga. Pohon kekerabatan dikonstruksi menggunakan metode Neighbor-joining dan Jarak genetik dianalisis dengan menggunakan metode Tamura-Nei yang terintegrasi dalam progam Geneious v5.6.4 (Kearse et al, 2012).

\section{Hasil dan Pembahasan}

Amplifikasi DNA gen COI sampel P. xylostella dari Modoinding (Modoinding1, Modoinding2, Modoinding3) dan Tomohon (Tomohon1, Tomohon2, Tomohon3) dengan teknik PCR, memperlihatkan hasil pola pita yang terlihat cukup jelas (Gambar 1). Berdasarkan ukuran DNA ladder dengan panjang $1 \mathrm{~kb} \quad(10.000 \mathrm{bp})$ sebagai pembanding, menunjukkan panjang gen COI pada enam sampel P. xylostella di lokasi berbeda. Gen COI pada enam sampel yang berhasil teramplifikasi berukuran 700 bp. Modifikasi primer yang digunakan untuk amplifikasi gen COI dikhususkan pada ordo Lepidoptera yaitu Lep_F1 dan Lep_R1 (Hebert et al, 2004) berhasil teramplifikasi, sehingga primer 
menempel pada gen COI dari enam sampel $P$. xylostella, dan menghasilkan pola pita yang jelas.

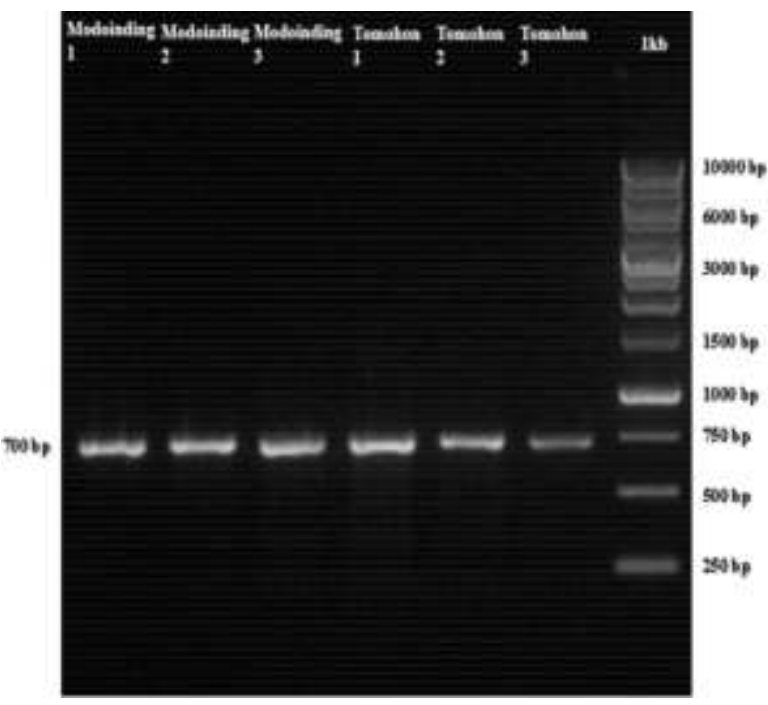

Gambar 1. Visualisasi hasil amplifikasi fragmen gen COI P. xylostella

Penjajaran kedua sampel dengan menggunakan program Multalin (Corpet, 1988) memperlihatkan adanya variasi (Gambar 2). Berdasarkan hasil analisis pada variasi susunan gen COI, sampel $P$. xylostella di lokasi yang berbeda menunjukkan adanya variasi gen pada tingkat nukleotida. Kebanyakan variasi gen yang terbentuk tidak mengubah susunan asam amino pada hampir semua sekuens sampel. Kasus berbeda ditemukan dalam sampel Tomohon1. Sampel Tomohon1 memiliki perbedaan pada asam amino dibandingkan sampel yang lain, diakibatkan oleh variasi yang terbentuk akibat perbedaan pada susunan triplet asam nukleotida. Tomohon1 memiliki triplet basa nukleotida CAT yang mengkodekan asam amino Histidine $(\mathrm{H})$ semi essensial, sedangkan kelima sampel lainnya memiliki triplet basa nukleotida CGT yang mengkodekan asam amino Asam Arginine (R) yang juga merupakan asam amino semi essensial.

Adanya variasi genetik gen COI yang terbentuk pada sampel $P$. xylostella di Modoinding dengan Tomohon kemungkinan besar disebabkan oleh pengaruh mutagen, sehingga mengakibatkan mutasi pada gen ini. Hal ini disebabkan karena tidak adanya mekanisme pemulihan (proofreading) pada DNA mitokondria, sehingga kemungkinan terjadinya kesalahan pada saat replikasi atau transkripsi menjadi tinggi (Murray et al, 2014). Menurut Hawkes et al (2004), berubahnya basa nukleotida yang kemudian mengubah asam amino yang dikodekan dipengaruhi oleh mutasi salah arti (missense mutation). Jenis mutasi ini dapat disebabkan oleh peristiwa transisi dan tranversi. Richard (2013), menegaskan, perubahan pada asam amino dapat menghasilkan fenotip mutan apabila asam amino yang berubah merupakan asam amino esensial. Menurut Zhou et al (2010), perubahan basa nukleotida tanpa mengubah asam amino yang dikodekan disebabkan oleh mutasi diam (silent mutation), mutasi ini tetap menghasilkan asam amino yang identik meskipun satu pasang basa nukleotida berubah. Mutasi ini disebabkan oleh peristiwa transisi dan tranversi.

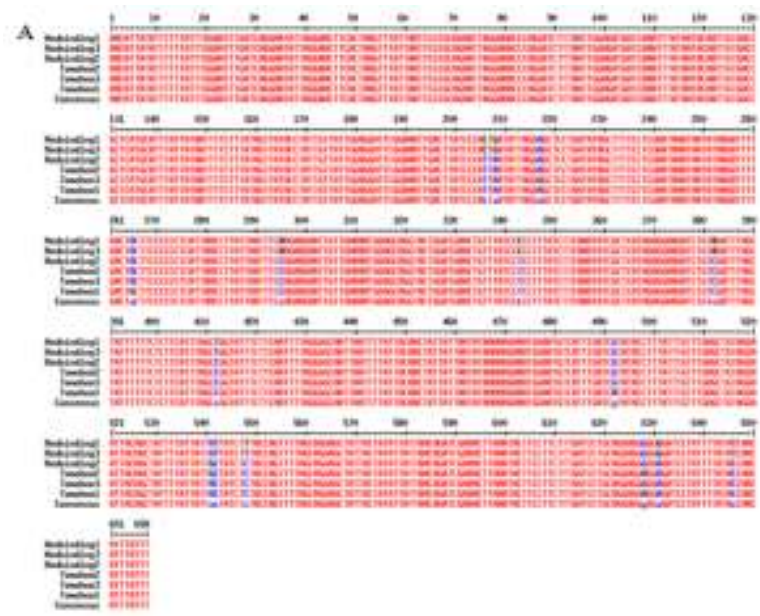

B

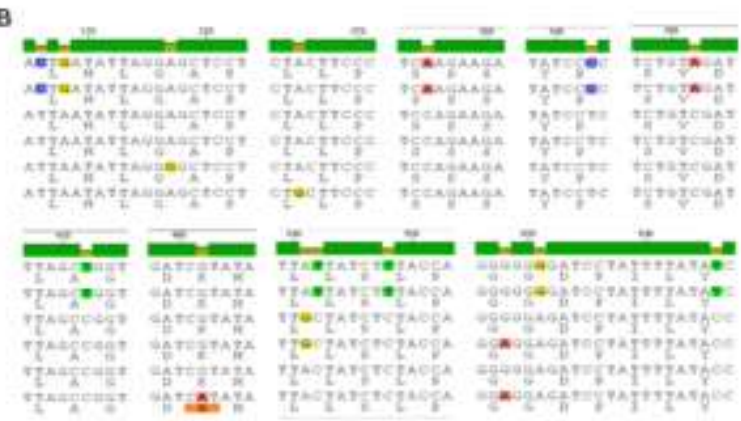

Gambar 2. Penjajaran sekuens sampel $P$. xylostella Modoinding dan Tomohon (A). Penjajaran Nukleotida, (B). Penjajaran Asam Amino

Meskipun berbeda lokasi dan terisolasi cukup jauh, dari hasil penjajaran $P$. xylostella Modoinding dan Tomohon dengan P. xylostella dalam GenBank (Australia, Canada, China, Holland, India, Israel, UK dan US) menunjukkan adanya variasi pada nukleotida (Gambar 3). Keidentikan yang tinggi ditunjukkan oleh sampel Modoinding dengan sampel yang berasal dari Australia dan India. Sampel yang berasal dari India 100\% identik dengan sampel Modoinding1 dan Modoinding3, sedangkan sampel yang berasal dari Australia 100\% identik dengan sampel Modoinding2 meskipun terpisah jarak lokasi yang jauh. Untuk sampel lain hanya memiliki perbedaan antara 1-14 basa nukleotida dari 658 total basa nukleotida keseluruhan yang artinya keidentikan keseluruhan sampel mencapai 99\%. Jianhong et al (2006), melaporkan bahwa keidentikan gen COI pada sampel berbeda lokasi ditemukan pada populasi yang berasal dari China dan Korea, selain itu Kim et al (2000), melaporkan P. xylostella yang berasal dari Hawaii menunjukkan keidentikan dalam variasi gen COI dengan hanya berbeda satu nukleotida dengan sampel yang berasal dari korea. 
Keidentikan nukleotida yang tinggi pada $P$. xylostella yang ditemukan dalam basis data Genbank kemungkinan disebabkan oleh migrasi pada populasi, sehingga memungkinkan $P$. xylostella mewariskan sifat genetiknya pada populasi lain di lokasi yang berbeda (Wei et al, 2013). Chapman et al (2002) melaporkan bahwa melimpahnya populasi $P$. xylostella dan menghasilkan generasi setiap tahun, mengharuskan serangga ini untuk bermigrasi ribuan kilometer. Dosdall et al (2001) menyatakan, Infestasi serangga ini pada bagian barat Canada berasal dari US atau Meksiko saat angin kencang membawa imago bermigrasi ke utara pada musim semi. Menurut Endersby et al (2003) kemunculan P. xylostella di Australia karena migrasi dari populasi bagian utara.

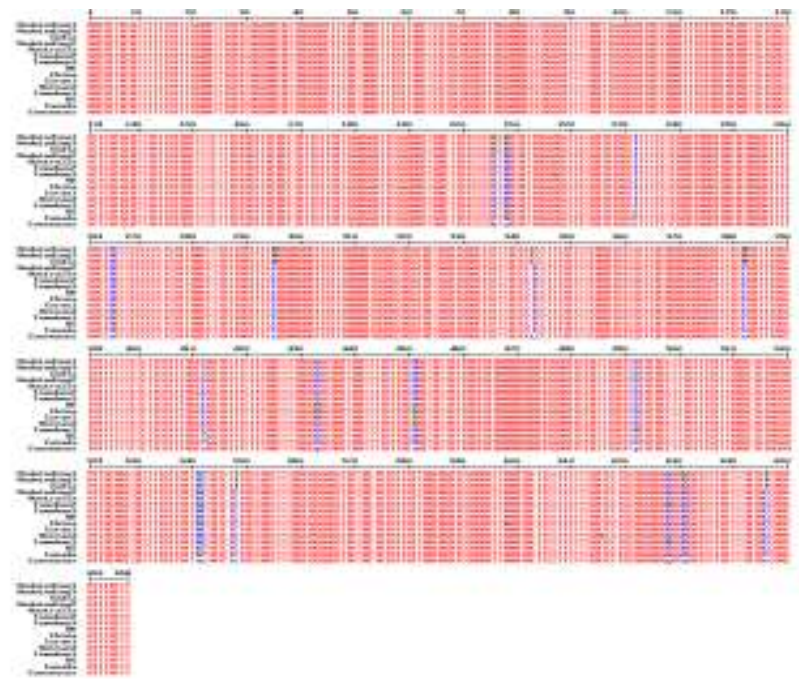

Gambar 3. Penjajaran sekuens sampel $P$. xylostella dari Modoinding dan Tomohon dengan sampel dalam Genbank

Berdasarkan hasil pohon kekerabatan (Gambar 4). Identiknya panjang cabang menunjukkan bahwa spesies memiliki rata-rata laju substitusi basa nukleotida yang sama dalam hitungan waktu tertentu. Sebaliknya, perbedaan panjang cabang menunjukkan perubahan pada laju substitusi basa nukleotida, sehingga jumlah perubahan substitusi basa nukleotida dalam hitungan waktu tertentu akan lebih besar jika cabang semakin panjang (Dharmayanti et al, 2011). Sampel Modoinding1 dan Modoinding3 terpisah dengan sampel lain pada lokasi berbeda. Hal ini menguatkan dugaan bahwa sampel yang berasal dari Modoinding mengalami perubahan pada laju substitusi nukleotida yang berbeda diakibatkan oleh faktor di lingkungan.

Sampel Modoinding1 dan Modoinding3 memiliki laju substitusi basa nukleotida yang sama dengan sampel yang berasal dari India. Hal serupa ditunjukkan oleh sampel Modoinding2 dengan Australia, namun kedua sampel ini masih dalam satu percabangan yang sama dengan sampel lainnya. Kumar et al (2017) dan Gautam et al (2018) menyatakan, akibat pemberian berbagai jenis insektisida di India secara terus-menerus, menyebabkan $P$. xylostella tidak mempan dengan berbagai macam pemberian insektisida. Selain itu, Bhat dan Bhagat (2008) melaporkan tingkat parasitasi berbagai macam parasitoid di India dengan nilai paling tinggi mencapai 57\% lebih rendah dibandingkan dengan tingkat parasitasi di daerah Tomohon yang mencapai 80\% (Bakri et al, 2015; Baideng, 2017). Hal tersebut menguatkan dugaan bahwa terpisahnya kelompok ini dengan laju substitusi nukleotida yang berbeda disebabkan oleh faktor dari lingkungan akibat pengaruh insektisida dan kurangnya parasitasi.

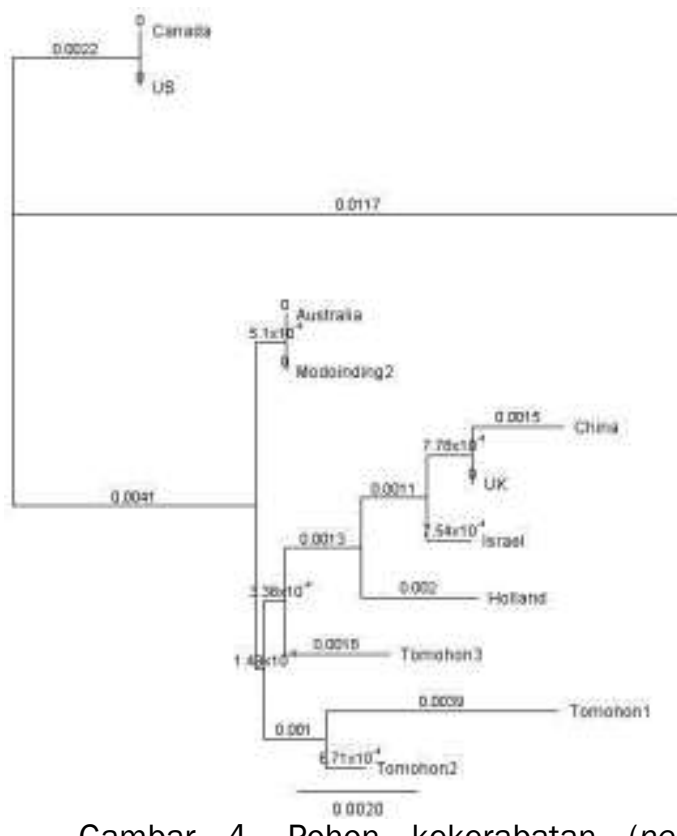

Gambar 4. Pohon kekerabatan (neighborJoining) P. xylostella dari Modoinding dan Tomohon dengan sampel dalam Genbank.

Berdasarkan hasil, nilai jarak genetik ( $p$ distance) bervariasi antara sampel Modoinding dan Tomohon dengan sampel yang berasal dari basis data Genbank (Tabel 1). Perbedaan jarak genetik pada sampel Modoinding (Modoinding1, Modoinding2, Modoinding3) dan sampel Tomohon (Tomohon1, Tomohon2, Tomohon3) berkisar antara 0-0,017 (0-1,70\%). Keseluruhan Perbedaan jarak genetik untuk semua sampel $P$. xylostella pada penelitian ini berkisar antara 0-0,022 (0-2,20\%). Jarak genetik (intraspecific p-distance) COI pada berbagai jenis serangga bervariasi. Untuk membedakan kategori intraspesies capung (Odonata) berkisar antara 0-0,035 (0-3,50\%) sedangkan untuk membedakan kategori interspesies (interspecific p-distance) berkisar antara 0,03-0,186 (3-18,60\%), untuk lepidoptera jenis ngengat (Heterocera) variasi intraspesies berkisar antara 0-0,097 (0-9,7\%) dan variasi interspesies berkisar antara 0,016-0,228 (1,6$22,80 \%$ ), sedangkan pada lepidoptera jenis kupukupu (Rhopalocera) variasi intraspesies berkisar 00,049 (0-4,9\%).

Semakin besar nilai jarak genetik ( $p$-distance) diantara populasi atau individu maka semakin terisolasi antara satu dengan lainnya, jarak genetik 
menunjukkan kemungkinan adanya pengaruh isolasi geografis terhadap suatu populasi (Schmitt dan Haubrich, 2008; Laltanpuii et al, 2014; Liu et al, 2014). Perbandingan keenam sampel $P$. xylostella di berbeda lokasi (Modoinding dan Tomohon) dengan sampel $P$. xylostella dari delapan lokasi berbeda yang berasal dari Genbank memiliki nilai $p$-distance antara $0-0,022(0-2,20 \%)$, dengan begitu sampel $P$. xylostella dalam penelitian ini masih tergolong dalam kisaran variasi intraspesies dengan sampel lainnya yang memiliki lokasi berbeda.

Tabel 1. Jarak genetik (\%) $P$. xylostella dari Modoinding dan Tomohon dengan sampel dalam Genbank.

\begin{tabular}{|c|c|c|c|c|c|c|c|c|c|c|c|c|c|c|c|}
\hline So & Sampel & 1 & 2 & 3 & 4 & 5 & 6 & 7 & 8 & 9 & 10 & 11 & 12 & 13 & 14 \\
\hline 1 & A Estralia & & 0,5 & 0,5 & 0,5 & 1,7 & 0,5 & 1,7 & 0,0 & 1,7 & 0,6 & 0.2 & 0,3 & 0,3 & 0,6 \\
\hline 2 & Canste & 0,6 & & 1,1 & 1,1 & 1,4 & 1,1 & 1,4 & 0,6 & 1,4 & 1,2 & 0.8 & 0,9 & 0,9 & 0,0 \\
\hline 3 & Chine & 0,5 & 1,1 & & $Q, 6$ & 22 & 0,3 & 22 & 0,5 & 22 & 1,1 & 0,6 & 0,8 & 0,2 & 1,1 \\
\hline 4 & Holland & 0,5 & 1,1 & 0.6 & & 19 & 0,3 & 1,9 & 0,5 & 19 & 0,8 & 0,6 & 8,5 & 0,5 & 1,1 \\
\hline 5 & ledia & 1,7 & 1,4 & 22 & 1,9 & & 1,9 & 0,0 & 1,7 & 0,0 & 2,0 & 19 & 1,7 & 20 & 1,4 \\
\hline 6. & Isreel & 0,5 & 1,1 & 0.3 & 0,3 & 19 & & 1,9 & 0.5 & 19 & 0,8 & 0,6 & 0,5 & 0,2 & 1,1 \\
\hline 7 & MI & 1,7 & 1,4 & 22 & 1,9 & 0,0 & 19 & & 1,7 & 0,0 & 2,0 & 19 & 1,7 & 2,0 & 1,4 \\
\hline 3 & $\mathrm{M} 2$ & 0,0 & 0,5 & 05 & 0,5 & 1,7 & 0,5 & 1.7 & & 1.7 & 0,6 & 0.2 & 0,3 & 0.3 & 0,6 \\
\hline 9 & M3 & 1,7 & 1,4 & 22 & 1,9 & 0,0 & 1,9 & 0,0 & 1,7 & & 2,0 & 19 & 1,7 & 2,0 & 1,4 \\
\hline 10 & $\mathrm{T1}$ & 0,6 & 1,2 & 1,1 & 0,8 & 20 & 0,8 & 20 & 0,6 & 20 & & 0,5 & 0,6 & 0,9 & 1.2 \\
\hline II & $\mathrm{I} 2$ & 0,2 & 0,8 & 0,6 & 0,5 . & 19 & 0,6 & 19 & 0,2 & 19 & 0,5 & & 0,5 & 0,5 & 0,8 \\
\hline 12 & T3 & 0,3 & 0,9 & 0.8 & 0,5 & 1,7 & 0,5 & 1,7 & 0,3 & 1.7 & 0,6 & 0,5 & & 0,6 & 09 \\
\hline 13. & UK & 0,3 & 0,9 & 0.2 & 0,5 & 20 & 0,2 & 20 & 0,3 & 20 & 0,9 & 0,5 & 0,6 & & 0.9 \\
\hline 14 & Us & 0,6 & 0,0 & 1,1 & 1,1 & 1,4 & 1,1 & 1,4 & 0,6 & 1,4 & 1,2 & 0,8 & 0.9 & 0,9 & \\
\hline
\end{tabular}

\section{Kesimpulan}

Sekuens gen COI P. xylostella di berbeda lokasi (Tomohon dan Modoinding) menunjukkan adanya variasi. Variasi ditunjukkan dengan adanya perbedaan pada pasang basa nukleotida dan asam amino. Perbandingan sekuens gen COI $P$. xylostella antara sampel yang diperoleh dari Genbank dengan sampel yang berbeda lokasi, menunjukkan adanya perbedaan 0-14 pasang basa nukleotida dengan Modoinding, dan 1-13 pasang basa nukleotida serta 1 asam amino dengan Tomohon. Hubungan kekerabatan gen $\mathrm{COI} P$. xylostella keseluruhan sampel tergolong dalam variasi intraspesies dengan nilai jarak genetik berkisar antara 0-0,022 (0$2,20 \%)$.

\section{Daftar Pustaka}

Ashfaq. M., S. Akhtar, A. M. Khan, S. J. Adamowicz and P. D. N. Hebert. 2013. DNA Barcode Analysis of Butterfly Species from Pakistan Points Towards Regional Endemism. Molecular Ecology Resources. 13 (5):832-843

Baideng. E. L. 2017. Plutella xylostella Parasitoid Parasitation Type and Percentage on Cabbage Vegetable Farm, in Rurukan Area, Tomohon, Indonesia. Scientific Papers Series Management, Economic Engineering in Agriculture and Rural Development. 17 (3): 7578.
Bakri. M. S. N., M. F. Dien dan D. S. Kandowangko. 2015. Parasitasi Diadegma semiclausum Hellen (Hymenoptera: Ichneumonidae) pada Hama Plutella xylostella (Lepidoptera; Plutelidae) di Tomohon. Cocos. 6 (16): 1-4.

Bhat. D. M. dan R. C. Bhagat. 2008. Studies on parasitoids of cabbage diamondback moth, Plutella xylostella (L.) (Lepidoptera: Plutellidae) in Kashmir Valley. Journal of Entomological Research. 32 (4): 303-308.

J. R. Riley, D. E. Pedgley and I. P. Woiwod. 2002. High-altitude migration of the diamondback moth Plutella xylostella to the U.K.: a study using, aerial netting, and ground tapping. Ecological Entomology 27 (1): 641-650.

Dharmayanti. N. L. P. I. 2011. Filogenetika Molekuler: Metode Taksonomi Organisme Berdasarkan Sejarah Evolusi. WARTAZOA. 21 (1):1-10.

Dosdall. L. M., P. G. Mason, O. Olfert, L. Kaminski and B. A. Keddie. 2001. The origins of infestations of diamondback moth, Plutella xylostella (L.), in canola in western Canada. Proceedings of the 4th International Workshop. 1 (1): 95-100.

Endersby. N., A. Weeks, S. McKechnie and P. Ridland. 2003. Development of genetic markers to study dispersal of Diamondback moth, Plutella xylostella (L.) in Australia. 13th Australian Research Assembly on Brassicas Conference Proceedings. 1 (1): 60-63.

Folmer. O., M. Black, W. Hoeh, R. Lutz, and R. Vrijenhoek. 1994. DNA Primers for Amplification of Mitochondrial Cytochrome $\mathrm{c}$ oxidase Subunit I from diverse metazoan invertebrates. Molecular Marine Biology and Biotechnology. 3 (5): 294-299.

Gautam. M.P., H. Singh, S. Kumar, V. Kumar, G. Singh and S. N. Singh. 2018. Diamondback moth, Plutella xylostella (Linnaeus) (Insecta: Lepidoptera: Plutellidae) a major insect of cabbage in India: A review. Journal of Entomology and Zoology Studies. 6 (4): 13941399.

Hawkes. N. J., R. W. Janes, J. Hemingway and J.Vontas. 2004. Detection of Ressistanceassociated Point Mutations of Organophosphate insensitive Acetylcholinesterase in the Olive Fruit Fly, Bactrocera oleae (Gmelin). Pesticide Biochemistry and Physiology 81: 151-163.

Hebert. P. D. N., E. H. Penton, J. M. Burns, D. H. Janzen and W. Hallwachs. 2004. Ten Species in one: DNA Barcoding Reveals Cryptic Species in the Neotropical Skipper Butterfly Astraptes fulgerator. Pnas. 101 (41):14812-14817.

Jianhong. L., F. Zhao, Y. Choi, I. Kim, H. Sohn and B. Jin. 2006. Genetic Variation in the Diamondback Moth, Plutella xylostella (Lepidoptera: Yponomeutidae) in China Inferred from Mitochondrial COI GeneSequence. Eur. J. Entomol. 103 (3): 605-611. 
Kambey. S. F., L. Kawet dan J. S. B. Sumarauw. 2016. Analisis Rantai Pasokan (Supply Chain) Kubis di Kelurahan Rurukan Kota Tomohon. Jurnal EMBA. 4 (5):303-408.

Kearse. M., R. Moir, A. Wilson, S. S.Havas, M. Cheung, S. Sturrock, S. Buxton, A. Cooper, S. Markowitz, C. Duran, T. Thierer, B. Ashton, P. Meintjes, and A. Drummond. 2012. Geneious Basic: an Integrated and Extendable Desktop Software Platform for the Organization and Analysis of Sequence Data.Bioinformatics Applications Note. 28 (12):1647-1649.

Kim. I., J. S. Bae, K. H. Choi, B. R. Jin, K. R. Lee and H. D. Sohn. 2000. Haplotype diversity and gene flow of the diamondback moth, Plutella xylostella (Lepidoptera: Yponomeutidae), in Korea. Korean J. Appl. Entomol. 39 (1): 43-52.

Kolondam. B. J., E. Lengkong, J. Polii-Mandang, A. Pinaria, dan S. Runtunuwu. 2013. Barcode DNA Anthurium Gelombang Cinta (Anthurium plowmanii) berdasarkan gen rbcL dan matK). Jurnal Bioslogos. 3 (1):17-25.

Kumar. A., R. S. Rana, K. C. Sharma and V. G. S. Chandel. 2017. Studies on genetic variability of Diamondback moth, Plutella xylostella (Lepidoptera: Yponomeutidae) in Himachal Pradesh. Journal of Entomology and Zoology Studies. 5 (4): 617-621.

Laltanpuii. N., S. Kumar dan M. T. Mathai. 2014. Molecular and Phylogenetic Analysis of the Genus Orthetrum (Odonata: Anisoptera: Libellulidae) using Mitochondrial $\mathrm{COI}$ gene. Science Vision 14(3): 152-257.

Liu. X. F., C. H. Yang, H. L. Han, R. D. Ward and A. Zhang. 2014. Identifying Species of Moths (Lepidoptera) from Baihua Mountain, Beijing, China, using DNA Barcodes. Ecol evol. 4(12): 2472-2487.

Lubenow. H., M. Scherer and D. Herold. 2008. Automated Extraction of Forensic Samples Using Established Spin Column Technology on the QIAcube. RdanD Department QIAGEN: Germany.

Mallet. J. 1989. The Evolution of Inscticide Resistance: Have the Insects Won?. TREE. 4 (11):336-340.

Murray. R. K., D. A. Bender, K. M. Botham, P. J. Kennelly, V. W. Rodwell dan P. A. Weil. 2014. Biokimia harper edisi 29. Penerbit buku kedokteran EGC: Jakarta.

Pandeirot. W. P., N. N. Wanta dan B. A. N. Pinaria. 2015. Populasi Larva Plutella xylostella pada Tanaman Kubis di Kelurahan Paslaten Kecamatan Tomohon Timur Kota Tomohon. Cocos. 6 (10):1-11.

Perez. C. J. and A. M. Shelton. 1997. Resistance of Plutella xylostella (Lepidoptera: Plutellidae) to Bacillus thuringiensis Berliner in Central America. Journal of Economic Entomology. 90 (1): 87-93.

Prabaningrum. L., T. S. Uhan, U. Nurwahidah. Karmin dan A. Hendra. 2013. Resistensi Plutella xylostella terhadap Insektisida yang Umum Digunakan oleh Petani Kubis di Sulawesi Selatan. J. Hort. 23 (2):164-173.

Richard. H. 2013. The Molecular Genetics of Insecticide Resistance. Genetics. 194: 807-815.

Schmitt. T. and K. Haubrich. 2008. The Genetic Structure of the Mountain Forest Butterfly Erebia euryale Unravels the Late Pleistocene and Postglacial History of The Mountain Coniferous Forest Biome in Europe. Molecular ecology 17(9): 2194-2207.

Tallei. E. T., R. Koneri and B. J. Kolondam. 2017. Sequence Analysis of the Cytochrome C Oxidase Subunit I Gene of Pseudagrion pilidorsum (Odonata: Coenagrionidae). Makara Journal of Science. 21 (1): 43-52.

Tarandung. E. S. 2016. Peranan Dinas Pertanian Kabupaten Minahasa Selatan dalam Pemberdayaan Petani Hortikultura di Kecamatan Modoinding. Jurnal Eksekutif. 1 (7):2-16.

Tarwotjo. U., J. Situmorang, R. C. H. Soesilohadi dan E. Martono. 2014. Monitoring Resistensi Populasi Plutella xylostella, L. Terhadap Residu Emamektin Benzoat di Sentra Produksi Tanaman Kubis Propinsi Jawa Tengah. Jurnal Manusia dan Lingkungan. 21 (2): 202212.

Udiarto. B. K. dan W. Setiawati. 2007. Suseptibilitas dan Kuantifikasi Resistensi 4 Strain Plutella xylostella L. terhadap beberapa insektisida. J. Hort. 17 (3): 277-284.

Wei. S., B. Shi, Y. Gong, G. Jin, X. Chen and X. Meng. 2013. Genetic Structure and Demographic History Reveal Migration of the Diamondback Moth Plutella xylostella (Lepidoptera: Plutellidae) from the Southern to Northern Regions of China. Plos one. 8 (4): 1-14.

Wilson J. J., K. Sing and M. Sofian-azirun. 2013. Building a DNA Barcode Reference Library for the True Butterflies (Lepidoptera) Of Peninsula Malaysia: What about the Subspecies?. Plos One. 8 (11)1-10.

Zhou. T., W. Gu and C. O. Wilke. 2010. Detecting Positive and Purifying Selection at Synonymous Sites in Yeast and Worm. Mol.Biol.Evol. 27 (8): 1912-1922. 